\title{
DETERMINAN POLA KONSUMSI MAHASISWA YANG BEKERJA DI STIE TRI DHARMA NUSANTARA
}

\author{
Adya Utami Syukri \\ Email : adya.utami@gmail.com \\ Program Studi Manajemen STIE Tri Dharma Nusantara \\ Jalan Kumala 2 No. 51, Makassar \\ Rahmatia \\ Email : rahmatiayunus@gmail.com \\ Program Studi Ilmu Ekonomi Universitas Hasanuddin \\ Jl. Perintis Kemerdekaan KM.10, Makassar
}

\begin{abstract}
ABSTRAK
Kegiatan ekonomi masyarakat digerakkan oleh kebutuhan manusia yang dari hari ke hari dan masa ke masa semakin meningkat dan beraneka ragam megikuti perkembangan zaman. Mahasiswa yang melakukan pekerjaan part time di sela-sela waktu kuliah tentu memiliki pola konsumsi yang berbeda. Penelitian ini bertujuan untuk mengetahui determinan pola konsumsi mahasiswa yang bekerja di STIE Tri Dharma Nusantara Makassar. Penelitian ini dilakukan kepada 52 mahasiswa STIE Tri Dharma Nusantara dengan menggunakan metode regresi linear berganda. Dalam penelitian ini dilakukan Teknik pengambilan sampel yakni accidental sampling. Hasil penelitian yang telah dilakukan berdasarkan ordinary least square menunjukkan ketiga variable bersifat valid secara simultan. Variable pendapatan berpengaruh negative, sementara variable gaya hidup dan tingkat harga berpengaruh positif terhadap konsumsi non makanan. Secara parsial, variable gaya hidup berpengaruh signifikan sedangkan variable pendapatan dan tingkat bunga berpengaruh tidak signifikan. Uji determinasi menunjukkan $20,8 \%$ variable dependen dijelaskan oleh variable independent.
\end{abstract}

Kata kunci : Konsumsi ; Pendapatan ; Gaya Hidup ; Tingkat Harga ; Mahasiswa

\section{ABSTRACT}

The economic activities of society are driven by human needs, which are increasing from day by day and from time to time. Students who do part-time work on the sidelines of lecture time certainly have different consumption patterns. This study aims to determine the determinants of consumption patterns of students who work at STIE Tri Dharma Nusantara Makassar. This research was conducted on 52 students of STIE Tri Dharma Nusantara using multiple linear regression methods. In this research, a sampling technique is used, namely accidental sampling. The results of research that have been done based on ordinary least square shows that all three variables are valid simultaneously. Income variable has a negative effect, while lifestyle variable and price level have a positive effect on non-food consumption. Partially, lifestyle variable have a significant effect while income and interest rates have no significant effect. The determination test shows that $20.8 \%$ of the dependent variable is explained by the independent variable.

Keywords: consumption; Income; Lifestyle ; Price Level; College students 


\section{PENDAHULUAN}

Kegiatan ekonomi masyarakat digerakkan oleh kebutuhan manusia yang dari hari ke hari dan masa ke masa semakin meningkat dan beraneka ragam megikuti perkembangan zaman. Seperti diketahui bersama kebutuhan manusia tak terbatas, namun harus dibedakan yang mana merupakan kebutuhan dan keinginan.

Masing-masing individu maupun rumah tangga melakukan kegiatan konsumsi untuk memenuhi kebutuhan berdasarkan pendapatan yang diperoleh. Stabilitas perekonomian dipengaruhi oleh konsumsi. Dengan adanya peningkatan konsumsi maka kegiatan ekonomi akan semakin meningkat sehingga stabilitas ekonomi dapat terpenuhi. Zaman yang semakin berkembang juga mendorong perubahan kebutuhan manusia. Kebutuhan manusia bukan lagi sekedar kebutuhan pakaian, rumah, dan makanan tetapi juga menyangkut kesehatan, gaya hidup, komunikasi, dan lain sebagainya (Perkasa, 2012).

Pada dasarnya manusia tidak pernah merasa puas sehingga mereka akan selalu berusaha untuk memenuhi kebutuhannya secara terus menerus. Kegiatan mengkonsumsi barang dan jasa yang dilakukan didasarkan pada beberapa factor misalnya saja pendapatan, gaya hidup, dan harga. Dalam perhitungan pendapatan nasional, pengeluaran konsumsi menjadi salah satu tolok ukur untuk melihat kesejahteraan ekonomi di suatu negara, dalam hal ini dari sisi pengeluaran. Keynes dalam (Reksoprayitno, 2000) berpendapat bahwa pengeluaran konsumsi berpengaruh secara proporsional terhadap pendapatan nasional dimana peningkatan pendapatan nasional akan menyebabkan kenaikan pengeluaran konsumsi.

Terkadang konsumen tidak membedakan apakah keperluan itu merupakan kebutuhan atau keinginan. Jika kegiatan membeli yang dilakukan untuk memenuhi kebutuhan maka hal itu merupakan hal yang seharusnya. Namun, jika kegiatan membeli dilakukan untuk memenuhi keinginan maka kegiatan ini merupakan kegiatan konsumtif. Perilaku konsumtif kini tidak hanya dialami oleh masyarakat umum, namun juga mulai merambah ke kalangan mahasiswa. Mahasiswa dipandang sebagai konsumen yang sudah dapat menerima penghasilan atau upah dari bekerja.

Menurut (Mankiw, 2013) kegiatan belanja untuk keperluan rumah tangga barang dan jasa disebut konsumsi. Barang merupakan kegiatan belanja rumah tangga untuk produk seperti makanan, mobil, pakaian, dan lain sebagainya. Sementara jasa merupakan kegiatan belanja 
rumah tangga untuk segala sesuatu yang tidak terlihat wujudnya misalnya kesehatan, bengkel, Pendidikan, asuransi, dan lain sebagainya.

(Diulio, 1993) berpendapat bahwa konsumsi terdiri atas dua jenis yakni konsumsi rutin dan konsumsi sementara. Konsumsi rutin yaitu pengeluaran untuk pembelian barang dan jasa yang secara terus menerus dikeluarkan sementara konsumsi sementara yaitu pengeluaran untuk pembelian barang dan jasa diluar konsumsi rutin. Di sisi lain (Deliarnov, 1995) dan (Samuelson \& Nordhaus, 1992) menyatakan bahwa komsumsi merupakan salah satu bagian dari pendapatan yang dibelanjakan untuk pembelian barang-barang dan jasa-jasa untuk mendapatkan kepuasan dan memenuhi kebutuhan”.

Teori - Teori Konsumsi yang Mendasari: Pertama, Teori Konsumsi John Maynard Keynes. Teori Keynes melihat konsumsi berdasarkan introspeksi dan observasi dengan menggunakan analisis statistik. Dalam teori Keynes menduga bahwa kecenderungan mengkonsumsi marginal (marginal propensity to consume) dalam setiap tambahan pendapatan adalah antara nol dan satu dimana rasio konsumsi terhadap pendapatan, kecenderungan mengkonsumsi ratarata (average propernsity to consume) turun ketika pendapatan naik karena sebagian sisa dari pendapatannya dialokasikan untuk tabungan. Keynes melihat bahwa pendapatan seseorang tidak sepenuhnya digunakan untuk konsumsi tetapi juga digunakan untuk menabung. Keinginan untuk menabung tentu saja selain didasarkan oleh pendapatan juga melihat tingkat bunga.

Berdasarkan teori Keynes diatas, dapat ditarik kesimpulan bahwa konsumsi sangat dipengaruhi oleh besarnya pendapatan. Demikian juga pada konsumsi mahasiswa. Pendapatan mahasiswa berasal dari pendapatan atau upah yang mereka peroleh setiap bulannya. Semakin tinggi pendapatan yang diperoleh maka akan semakin besar pula pengeluaran konsumsinya, begitu juga sebaliknya. Sementara kegiatan menabung di kalangan mahasiswa masih tergolong rendah.

Kedua, Teori Konsumsi Milton Friedman, dimana pendapatan dapat digolongkan menjadi 2, yaitu pendapatan permanen (Permanen Income) dan pendapatan sementara (Transitory Income). Pendapatan permanen yaitu pendapatan yang selalu diterima pada setiap periode tertentu dan dapat diperkirakan sebelumnya, misalnya pendapatan dari gaji atau upah. 
Sedangkan pendapatan sementara adalah pendapatan yang tidak bisa diperkirakan sebelumnya dan tidak selalu diterima pada setiap periode.

Berdasarakan hipotesis yang disampaikan oleh Milton Friedman tentang konsumsi, menunjukan bahwa mahasiswa akan mengkonsumsi lebih banyak barang/jasa jika pendapatan sementara (bonus) naik di atas pendapatan permanen (penghasilan). Misalnya ketika bulan ini mahasiswa mendapatan upah sebesar A kemudian mereka memperoleh pendapatan sementara yaitu yang berasal dari bonus sebesar B maka pada bulan ini konsumsi mahasiswa akan naik secara temporer. Akan tetapi jika pada bulan selanjutnya pendapatan temporer mahasiswa turun dibawah pendapatan permanen maka konsumsinya akan turun. Jadi konsumsi mahasiswa itu tergantung dari pendapatan permanen, yaitu penghasilan yang diterima setiap bulan.

Ketiga, Teori Konsumsi Model Pilihan Antar Waktu Irving Fisher (Fishers Intertemporal Choice) menyatakan bahwa ketika seorang konsumen memutuskan berapa banyak pendapatan yang akan dikonsumsi dan berapa banyak yang akan ditabung, akan mempertimbangkan kondisi sekarang dan kondisi yang akan datang. Semakin banyak yang dikonsumsi saat ini, maka akan semakin sedikit yang bisa dikonsumsi di masa yang akan datang. Irving Fisher mengembangkan sebuah model konsumsi yang digunakan untuk menganalisis bagaimana konsumen secara rasional menentukan pilihan (intertemporal choice). Model Fisher menunjukan kendala yang dihadapi konsumen dan bagaimana mereka memilih antara konsumsi dan tabungan.

Berdasarkan teori konsumsi yang dikemukakan oleh Irving Fisher tentang pilihan antar waktu, mahasiswa dalam menggunakan pendapatannya perlu mempertimbangkan kondisi sekarang dan kondisi yang akan datang. Misalnya saat ini mereka mempunyai pendapatan sebesar A, dengan pendapatan sebesar A tersebut seorang mahasiswa harus benar-benar rasional dalam membelanjakannya. Karena jika mahasiswa membelanjakan semua pendapatannya tersebut untuk barang maupun jasa sekarang, maka akan semakin sedikit yang bisa dikonsumsi di masa yang akan datang.

Keempat, Teori Konsumsi Hipotesis Daur/Siklus Hidup (Life-Cycle Hypothesis) yang menerangkan bahwa pengeluaran masyarakat mendasarkan kepada kenyataan bahwa pola penerimaan dan pola pengeluaran konsumsi seseorang pada umumnya dipengaruhi oleh masa 
dalam siklus hidupnya. Selanjutnya, Modligani menekankan bahwa pendapatan bervariasi secara sistematis selama kehidupan seseorang dan tabungan membuat konsumen dapat mengalihkan pendapatan dari masa hidupnya ketika pendapatan tinggi ke masa hidup ketika pendapatannya rendah (Mankiw, 2007).

Berdasarkan Teori Konsumsi Hipotesis Daur hidup yang dikemukakan oleh Franco Modligani di atas, mencerminkan bahwa mahasiswa saat ini sedang berada pada usia muda, dimana kecenderungan menerima penghasilan/pendapatan/upah rendah dan mempunyai tabungan yang negatif. Mahasiswa memiliki tabungan yang negatif karena keseluruhan pendapatan yang diperoleh sepenuhnya dialokasikan untuk kegiatan konsumsi.

Beberapa peneliti sudah menganalisis pola konsumsi mahasiswa dari sudut pandang yang sama maupun berbeda. (Wahyuni, 2011) melihat pola konsumsi mahasiswa dari sisi management capability, status ekonomi social, pengetahuan tentang konsep ekonomi, dan perilaku konsumen. Sementara itu, (Mulyani, 2015) melihat pola konsumsi non makanan mahasiswa berdasarkan jenis kelamin dan angkatan tahun kuliah mahasiswa. Adapun (Faizal, 2019) melihat pola konsumsi untuk mahasiswa indekos. Penelitian dari sisi berbeda dilakukan oleh (Yoh et al., 2016) yang melihat utilitarian dan hedonis di kalangan mahasiswa America dalam pembelian sepatu atletik.

Mahasiswa adalah seseorang yang telah terdaftar di sebuah universitas dan memenuhi persyaratan lain yang ditetapkan oleh unversitas yang bersangkutan. Mahasiswa sama halnya dengan masyarakat dengan rumah tangga, juga melakukan aktivitas ekonomi sehari-hari termasuk konsumsi. Namun, pola konsumsi suatu masyarakat atau individu termasuk pola mahasiswa berbeda-beda satu sama lain.

Mahasiswa yang melakukan pekerjaan part time di sela-sela waktu kuliah tentu memiliki pola konsumsi yang berbeda. Selain menyiapkan anggaran untuk kebutuhan sehari-hari, mereka juga perlu untuk menyisihkan sebahagian penghasilan yang diperoleh untuk keperluan kuliah, misalnya pembayaran UKT (Uang Kuliah Tunggal), print tugas, dan sebagainya. Hal ini tentu berbeda bagi mahasiswa yang tidak melakukan pekerjaan part time. Mereka mendapatkan penghasilan dari orang tua mereka yang sering disebut jatah bulanan. Kebutuhan dasar bagi para mahasiswa antara lain, makanan, transportasi dan akomodasi, komunikasi, hiburan, dan biaya kuliah. 
Keadaan ini dapat juga terlihat di kalangan mahasiswa STIE Tri Dharma Nusantara Makassar dimana sebagian besar mahasiswanya adalah para pekerja part time, yakni mereka yang bekerja disela-sela waktu kuliah. Keputusan untuk mengambil pekerjaan disela-sela waktu kuliah tentu berdampak positif dan negatif. Positifnya adalah mereka dapat langsung terjun ke dunia kerja, mendapatkan penghasilan, dan dapat mengaplikasikan ilmu yang diterima secara langsung. Namun, penghasilan yang mereka terima tentu saja tidak sepenuhnya dapat dinikmati karena mereka harus menabung untuk keperluan perkuliahan. Sehingga sedikit banyak dapat mempengaruhi pola konsumsi yang mereka gunakan.

Berdasarkan uraian diatas, peneliti kemudian tertarik untuk melakukan penelitian mengenai determinan pola konsumsi mahasiswa yang bekerja di STIE Tri Dharma Nusantara.

\section{METODE PENELITIAN}

Penelitian ini menggunakan metode kuantitatif dengan pendekatan deskriptif. Metode kuantitaf yang dimkasud dalam hal ini yaitu penelitian pada responden mahasiswa yang bekerja di STIE Tri Dharma Nusantara dengan menggunakan Teknik pengumpulan data berupa observasi dan kuesioner. Analisis data digunakan dengan menggunakan metode regresi dengan Ordinary Least Square (OLS) melihat hasil secara statistic (Gujarati \& Porter, 2006)

Dalam penelitian ini peneliti bertujuan untuk mengetahui determinan pola konsumsi mahasiswa yang bekerja di STIE Tri Dharma Nusantara.

a. Sampel

Pengambilan sampel pada penelitian ini menggunakan Teknik Accidental Sampling. Hal ini dilakukan sebab peneliti hanya membatasi kriteria sampel adalah mahasiswa STIE Tri Dharma Nusantara yang bekerja sehingga peneliti mengambil sampel secara acak yang sesuai dengan kriteria tersebut.

b. Variabel Penelitian dan definisi operasional

Variabel penelitian yang digunakan dalam penelitian ini ada dua jenis yakni variable independent dan variable dependen.

- Variable dependen yakni konsumsi non makanan mahasiswa (Y). Konsumsi non makanan yang dimaksud disini yaitu pengeluaran mahasiswa untuk komunikasi, transportasi, entertainment, dan biaya penunjang perkuliahan. 
- Variable independent yaitu pendapatan (X1), gaya hidup (X2), dan tingkat harga (X3). Pendapatan adalah upah yang diterima oleh mahasiswa diukur dengan rupiah per bulan. Gaya hidup adalah kebiasaan belanja mahasiswa yang dipengaruhi oleh lingkungan tempat tinggal dan pendapatan yang diterima yang diukur melalui skala Linkert. Tingkat harga adalah nilai barang/jasa berdasarkan satuan ukur tertentu. Dalam hal ini ada tidaknya diskon atau potongan harga dan lain sebagainya.

c. Metode Analisis

- Analisis Regresi Linear Berganda

Model regresi linear berganda dengan menggunakan program Eviews. Rumus regresi linear berganda dapat dinyatakan sebagai berikut :

$$
Y=a+b_{1} X_{1}+b_{2} X_{2}+b_{3} X_{3}
$$

Keterangan :

$$
\begin{array}{ll}
\mathrm{Y} & =\text { Konsumsi Non Makanan } \\
\mathrm{X}_{1} & =\text { Pendapatan } \\
\mathrm{X}_{2} & =\text { Gaya Hidup } \\
\mathrm{X}_{3} & =\text { Tingkat Harga } \\
\mathrm{a} & =\text { konstanta } \\
\mathrm{b}_{1}, \mathrm{~b}_{2}, \mathrm{~b}_{3} & =\text { koefisien regresi }
\end{array}
$$

- Koefisien Determinasi

Merupakan besarnya kontribusi variable bebas terhadap variable tergantungnya. Semakin tinggi koefisien determinasi, semakin tinggi kemampuan variable independen dalam menjelaskan variasi perubahan pada variable dependen

- Uji t Parsial

Uji t digunakan untuk mengetahui pengaruh variable independent secara parsial terhadap variable dependen.

- Uji F Simultan

Digunakan untuk mengetahui pengaruh variable independent secara bersamaan terhadap variable dependen. 


\section{HASIL DAN PEMBAHASAN}

\section{Hasil}

Tabel 1. Hasil Regresi

Dependent Variable: Y

Method: Least Squares

Date: 03/03/20 Time: 21:35

Sample: 152

Included observations: 52

\begin{tabular}{crrrr}
\hline Variable & Coefficient & Std. Error & t-Statistic & Prob. \\
\hline C & & & & \\
X1 & 2.975171 & 0.383149 & 7.765041 & 0.0000 \\
X2 & -0.015248 & 0.115736 & -0.131751 & 0.8957 \\
X3 & 0.266633 & 0.088628 & 3.008448 & 0.0042 \\
& 0.131780 & 0.082025 & 1.606587 & 0.1147
\end{tabular}

\begin{tabular}{lllr} 
R-squared & 0.255010 & Mean dependent var & 4.168231 \\
Adjusted R-squared & 0.208448 & S.D. dependent var & 0.077596 \\
S.E. of regression & 0.069037 & Akaike info criterion & -2.434547 \\
Sum squared resid & 0.228773 & Schwarz criterion & -2.284452 \\
Log likelihood & 67.29823 & Hannan-Quinn criter. & -2.377004 \\
F-statistic & 5.476790 & Durbin-Watson stat & 2.610689 \\
Prob(F-statistic) & 0.002556 & & \\
\hline
\end{tabular}

Sumber : data primer diolah, 2020

\section{Pembahasan}

Berdasarkan Tabel 1 maka didapat persamaan regresi linear berganda sebagai berikut :

$$
Y=2,975-0,015 X_{1}+0,266 X_{2}+0,131 X_{3}
$$

a. Nilai konstanta (a) sebesar 2,975 menunjukkan bahwa jika pendapatan, gaya hidup, dantingkat harga sebesar 0 , maka konsumsi non makanan mahasiswa yang bekerja mengalami kenaikan sebesar 2,975 satuan.

b. Nilai koefisien variable pendapatan $\left(X_{1}\right)$ bernilai negative sebesar 0,015 menunjukkan bahwa setiap peningkatan pendapatan 1 satuan, maka konsumsi non makanan mahasiswa yang bekerja akan menurun sebesar 0,015 satuan. Dari uji t untuk variable pendapatan menunjukkan hubungan yang tidak signifikan yang berarti bahwa perubahan pada pendapatan tidak berpengaruh terhadap konsumsi non makanan. Pendapatan tidak berpengaruh terhadap konsumsi non makanan disebabkan seorang mahasiswa jika pendapatannya meningkat cenderung mengurangi pengeluaran untuk komunikasi, transportasi, entertainment, dan biaya penunjang perkuliahan. Mahasiswa sudah mulai mengambil keputusan secara rasional sesuai dengan teori Irving Fisher. Karakter mahasiswa yang mendapatkan 
penghasilan dari bekerja, tanpa uang saku dari orang tua, mendorong mereka untuk berpikir secara rasional ketika akan membelanjakan pendapatan yang mereka terima. Keputusan yang diambil kemudian terlihat bahwa mereka cenderung mengurangi kebutuhan akan komunikasi, transportasi, entertainment, dan biaya penunjang perkuliahan. Hal ini dilakukan misalnya dengan lebih menggunakan kuota internet untuk berkomunikasi daripada pulsa regular, tinggal lebih dekat dari kampus untuk menghemat biaya transportasi, mengurangi kegiatan hang out bersama teman-teman, dan memanfaatkan fasilitas kampus yang ada.

c. Nilai koefisien variable gaya hidup $\left(X_{2}\right)$ bernilai positif sebesar 0,266 satuan menunjukkan bahwa jika gaya hidup meningkat 1 satuan, maka konsumsi non makanan juga akan meningkat sebesar 0,266 satuan. Dari uji t untuk variable gaya hidup menunjukkan pengaruh signifikan dengan tingkat signifikansi $1 \%$ yang berarti bahwa gaya hidup memiliki pengaruh terhadap konsumsi non makanan. Gaya hidup berpengaruh positif terhadap konsumsi non makanan. Hal ini disebabkan dalam indicator gaya hidup meliputi lingkungan tempat tinggal dan alokasi pendapatan yang diterima. Ketika mahasiswa bertempat tinggal di kawasan yang cukup elite maka akan menambah pengeluaran mereka di bidang entertainment. Begitupun ketika teman bergaul mahasiswa merupakan anak gaul maka akan menambah pengeluaran mereka di sisi komunikasi dan transportasi. Pengaruh positif ini memiliki dampak negative dimana mahasiswa cenderung mengalokasikan pendapatan yang diterima lebih sedikit dari pengeluaran alias pengeluaran mereka lebih banyak dari pendapatan.

d. Nilai koefisien variable tingkat harga bernilai positif sebesar 0,131 satuan menunjukkan bahwa jika tingkat harga meningkat 1 satuan, maka konsumsi non makanan akan meningkat sebesar 0,131 satuan. Dari uji $\mathrm{t}$ untuk variable tingkat harga menunjukkan pengaruh yang tidak signifikan. Tingkat harga tidak berpengaruh terhadap konsumsi non makanan. Hal ini menunjukkan pengeluaran non makanan mahasiswa tidak mengikuti tingkat harga yang ada. Adanya diskon atau potongan harga menjadi hal yang juga dipertimbangkan oleh mahasiswa ketika 
akan berbelanja. Seperti diketahui tingkat harga dipengaruhi oleh inflasi dimana inflasi kota Makassar Februari 2020 sebesar 1,16\% sehingga harga relative konstan.

e. Uji Determinasi yang ditunjukkan dengan nilai Adjusted R Square sebesar 0,208. Hal ini berarti bahwa variable independent (pendapatan, gaya hidup, dan tingkat harga) dapat menjelaskan variable dependen (konsumsi non makanan) sebesar $20,8 \%$, sedangkan sebesar $79,2 \%$ dijelaskan oleh factor lain yang tidak dimasukkan dalam model.

f. Uji F (Simultan) yang ditunjukkan dengan nilai F-statistic sebesar 5,476 dengan probabilitas 0,002. Hal ini menunjukkan variable independent (pendapatan, gaya hidup, tingkat harga) secara simultan berpengaruh terhadap variable dependen (konsumsi non makanan)

\section{KESIMPULAN}

Berdasarkan hasil penelitian yang telah dijelaskan, maka dapat ditarik kesimpulan :

1. Pendapatan berpengaruh negative dan tidak signifikan terhadap konsumsi non makanan.

2. Gaya hidup berpengaruh positif dan signifikan terhadap konsumsi non makanan

3. Tingkat harga berpengaruh positif dan tidak signifikan terhadap konsumsi non makanan

4. Ketiga variable independent (pendapatan, gaya hidup, dan tingkat harga) secara simultan berpengaruh signifikan terhadap variable dependen (konsumsi non makanan)

5. Sebanyak 20,8\% variable independent (pendapatan, gaya hidup, dan tingkat harga) mampu menjelaskan mengenai variable dependent (konsumsi non makanan), sementara $79.8 \%$ dijelaskan oleh faktor-faktor lain yang tidak dimasukkan dalam model.

\section{DAFTAR PUSTAKA}

Deliarnov. (1995). Pengantar Ekonomi Makro. UI-Press.

Diulio, A. E. (1993). Teori Makro Ekonomi. Jakarta: Erlangga. 
Faizal, F. (2019). Analisis Faktor-Faktor yang Mempengaruhi Pola Konsumsi Mahasiswa Indekos UIN Alauddin Makassar. Universitas Islam Negeri Alauddin Makassar.

Gujarati, D. N., \& Porter, D. C. (2006). Dasar-dasar ekonometrika. Jakarta: Erlangga.

Mankiw, N. G. (2007). Makroekonomi edisi keenam. Jakarta: Erlangga.

Mankiw, N. G. (2013). Teori Ekonomi Makro. Salemba Empat.

Mulyani, S. (2015). Pola Konsumsi Non Makanan Mahasiswa Program Studi Pendidikan Ekonomi Fakultas Ekonomi Universitas Negeri Yoyakarta. Skripsi Tidak Diterbitkan. Yogyakarta: FE UNY.

Perkasa, A. A. (2012). Faktor-Faktor Yang Mempengaruhi Pola Konsumsi Mahasiswa UNHAS. Fakultas Ekonomi Universitas Hasanuddin Makassar: Skripsi Dipublikasikan.

Reksoprayitno, S. (2000). Ekonomi Makro: analisis IS-LM dan permintaan-penawaran agregatif. Badan Penerbit Fakultas Ekonomi (BPFE),[Universitas Gadjah Mada (UGM)].

Samuelson, P. A., \& Nordhaus, W. D. (1992). Makro-Ekonomi, Edisi Keempatbelas. Penerbit Erlangga. Jakarta.

Wahyuni, E. T. (2011). Faktor-faktor yang Mempengaruhi Perilaku Konsumsi Mahasiswa Fakultas Ekonomi Universitas PGRI Yogyakarta. Jurnal Akmenika Edisi Ke, 4, 1-15.

Yoh, T., Chen, H. Y., \& Jang, I. (2016). Utilitarian and Hedonic Consumption Values on American College Students' Athletic Footwear Purchase Intention. International Journal of Academic Research in Business and Social Sciences, 6(12), 307-320. 